\title{
INFLUENCE OF THE USAGE OF SOCIAL NETWORKING SITES ON ACADEMIC PERFORMANCE OF STUDENTS IN ENTREPRENEURSHIP EDUCATION
}

\author{
Stephen A. Igboke ${ }^{1 i}$, \\ Patricia Akwaya Olom² \\ ${ }^{1} \mathrm{PhD}$, Department of Business Education, \\ Ebonyi State University, \\ Abakaliki, Nigeria \\ ${ }^{2}$ Sr., Department of Vocational Education, \\ University of Calabar, \\ Calabar, Nigeria
}

\section{Abstract:}

The study investigated the influence of the usage of social networking sites on academic performance of students in Entrepreneurship Education. Two research questions and two hypotheses guided the study. The study adopted a descriptive survey design. The population consisted of 120 students (60 males and 60 females) from University of Calabar in Nigeria. A questionnaire with a-4-point rating scale was used to elicit responses from the respondents. The instrument was tested for reliability using Cronbach Alpha, and it yielded a reliability coefficient of 0.89 . Data collected were analyzed using mean and standard deviation to answer the research questions and t-test to test the hypotheses at a confidence level of 0.05 . The findings from the study revealed that the motives of students using social networking sites include: connecting with family and friends; searching for new friends; online news; entertainments; information sharing, chatting, downloading music and movies and searching for study materials. It was also found that the usage of social networking sites had strong positive influence on the students. Similarly, the test of hypotheses indicates that there is significant difference in the motive of using Social Networking Sites (SNSs) by male and female students in Entrepreneurship Education. Besides, it was found that there is a significant difference in the opinion of male and female respondents on the influence of social networking sites usage on the academic performance of male and female students in Entrepreneurship Education. The implication of the study is that social networking sites could be used as educational resource in order to improve academic performance of both male and female students. However, usage of the networking sites may also influence academic performance negatively. Teachers and counselors need to particularly take notice of this for necessary remedial actions. Based on the findings, it was recommended that

${ }^{\text {i Correspondence: email sigboke@yahoo.com }}$ 
Universities and lectures in particular should adopt the usage of social networking sites to enhance teaching and learning in Entrepreneurship Education and other related disciplines.

Keywords: usage of social networking sites, academic performance, entrepreneurship education

\section{Introduction}

Governments world over have been making frantic efforts to create jobs for its citizens as a way of reducing unemployment and poverty. In Nigeria, the efforts to create job, reduce unemployment and poverty are witnessed in the introduction of entrepreneurship education into the academic curriculum. According to Ediagbonya (2013), the call for the introduction of Entrepreneurship Education in schools is an indication that it is important in economic empowerment and job creation in particular.

Entrepreneurship is defined by Ejere and Tende in Olokundun, Ibidunni, Peter, Amaihian and Ogbari (2017) as the willingness and ability of a business minded individual to identify the areas of needs of people, look for resources to match these needs, combine these resources in the most optimum way, bears the un-insurable risk and established a successful and profitable venture. In the view of Timmons in Vakili, Tahmasebi, Tahmasebi and Tamasebi (2016), entrepreneurship is the ability to create knowledge out of nothing, the capacity to understand how to find, organize, and control the resources which are mostly in the hands of others. Entrepreneurship is a creative and innovative way of transforming ideas into productive ventures, value creation and addition, in order to satisfy the needs of others, and become successful as an entrepreneur. Entrepreneurship involves the ability to develop a positive attitude and belief towards risk taking, making rational judgment based on experience and knowledge acquired and efficient utilization of advantage skills in order to be successful in any given field in life. Advantage skills here imply the skills that give one an advantage over another. These skills can be developed through education and training. Donckels and Kantor in Vakili et al (2016) shared in the sentiment that individuals' entrepreneurial thinking can be enhanced through education.

Bringing education into entrepreneurship amounts to entrepreneurship education. Entrepreneurship education is focused in developing individuals' knowledge, experience, skills, attitudes and beliefs so that they can have a product or services to render to others and make a living out of it. Olokundun et al. (2017) defined entrepreneurship education as that type of education fashioned out to prepare learners for innovative ventures which lead to self-reliance and economic emancipation. Entrepreneurship Education, therefore, prepares one for employment or self-reliance. It is more of a practical programme, and this distinguishes it from other educational programmes. Moberg in Lackeus (2015) noted that entrepreneurship education consists of content, methods and activities supporting the creation of knowledge, competencies 
and experiences that make it possible for students to initiate and participate in entrepreneurial value creating processes. Furthermore, Opinkirjo (2012) asserted that the aims of entrepreneurship studies are to improve children's and adolescent's life management skills; promote citizenship; provide adolescents with resources for the future; provide children and adolescents with social and economic skills.

Entrepreneurship education is vital in the development of human capital which in turn enhances economic growth and development, increases productivity as well as encourage the creative and innovative ways of doing things. It is of great benefit to an individual or group of individuals, an organization and the entire society. With respect to these benefits, Vakili et al. (2016) opined that world's great universities have taken education and development of entrepreneurial thinking into account in their curriculum, and developing entrepreneurial skills and innovations has become a major educational concern in different societies. Similarly, the National University Commission (NUC) has made entrepreneurship education compulsory for all universities in Nigeria, University of Calabar inclusive.

Academic success of students in entrepreneurship education is a source of concern to the university communities, the society and the government in particular. The efforts of the universities in Nigeria to inculcate entrepreneurial skills in the students will be much appreciated by the society if university graduates can demonstrate entrepreneurial competencies, possess employability skills, and reduce unemployment by becoming selfreliant. However, there are indications that schools place much interest in standardize testing of students' entrepreneurial skills rather than developing these skills in them. Until these skills are properly developed in the students, the objectives of entrepreneurship education would be far from being realized. In many instances, academic performance is used interchangeably with academic achievement. In this regard, Wikipedia (2019) defined academic performance or achievement as the extent to which a student, teacher or institution has achieved their short or long-term education goals. This definition shows that academic performance is not only measured upon the students; but also on the teachers and the school. This is because teacher factor and the school factor affect the performance of the students. For instance, an educator with instructional related competences is likely to enhance the performance of the students. Also, an institution which has an enabling environment for learning, adequate facilities, and instructional resources is likely to encourage students' academic performance. However, individual differences of students can specifically influence academic performance. On this note, students with higher Intelligent Quotient (IQ) outperform those with lower IQ especially in examinations. From this perspective, academic performance is viewed by the Cambridge University Reporter (2003) in terms of examination performance. Though a student may not score excellently in examination, but may be excellent in other fields such as sports, leadership, mediation, and so on.

There are various factors that influence academic performance. Romer (1993) identified class attendance as one of the factors. It is argued that students who regularly attend classes are likely to perform better than those who are not regular. In addition, 
Haist, Wilson, Elam, Blue, and Fosson (2000) suggested that gender and age can influence performance. Other factors may include environment, parental academic interest, physical activities, family income, learning styles or preferences and the availability of learning resources. In recent times, there are many learning resources available online. More so, modern day technological revolution seems to have increased teachers and students' preferences in the use of Information and Communication Technology (ICT) in teaching and learning. ICT consist of the internet and information assisted medium such as satellite, cable data transmission, wireless networks, cell phones and computers. Additionally, ICT has promoted various forms of connections, popularly referred to as networking. Furthermore, networking comprises of phone networking, computer networking and social networking.

Social networking involves information sharing among people with strong connections or ties. Editorial Team (2016) defined social networking as a form of social media, used for interactive, educational, informational or entertaining purposes. However, the interaction of people in social networking is enhanced by the internet. Walker (2011) captured this by maintaining that the internet has given us the ability to connect with people from around the globe with a few clicks of buttons, making it easier than ever to keep in touch with family and friends.

Online social networking sites are normally hosted on web sites, referred to as social networking sites. According to Ekechukwu (2017), social networking sites are web sites that allow their users or members to share, send or receive information with selected group of friends or associates. Similarly, Boyd and Ellison (2008) defined social networking sites as web-based services that allow individuals to construct a public or semi-public profile within a bounded system, articulate a list of other users with whom they share a connection, and view or traverse their list of connections and those made by others within the system. Social networking sites are numerous. Jamie (2018) identified over sixty (60) social networking sites which could further be classified into social connections, multimedia sharing, professional, informational, educational hobbies and academic net working sites (White, 2021).

Social connections: This is social networking sites that help people to keep in touch with friends and family members. Examples include Facebook, Twitter, Google+, MySpace, WhatsApp, Tencent QQ, Line, Baidu and Vkontakte. Multimedia sharing allows the sharing of video and photographic content online. Examples include QZone, Instagram, Tumblr, YouTube, Flickr, Skype, Snapchat, StumbleUpon, Flixster, Buzzket, Funny or Die and We Heart it. Professional social networking sites are meant to provide opportunities for career related advancement. White (2021) posited that some of these types of networks provide a general forum for professionals to connect, while others are focused on specific occupations or interests. Some examples of the professional social networking sites include: LinkedIn, Classroom, Reverbnation, Viadeo, and Xing.

Informational social networking sites are designed to provide relevant information to interested members of the information communities. According to white (2018), countless blogs, websites, and forums are filled with people who are looking for 
the same kind of information. There are various forms of information people of like minds seek such as reproductive issues, home management, care of special children, security and so on. Examples of information social networking sites include Pinterest, Catemom, the Nature Conservancy and Do-It-Yourself Community.

Educational social networking sites in the opinion of White (2018) are where many students go in order to collaborate with other students on academic project, to conduct research for a school, or to interact with professors and teachers via blogs and classroom forums. Some examples of educational social networking sites are Classmates, The Student Room, The Math Forum and ePALS School Blog. Hobbies websites connect people based on their favorite hobbies. There are many people who like doing a particular thing as their hobby, such people are brought together by the hobbies social networking sites such as Grow It!; Tagged, The Dots, Care2, DevianArt and My Place at Scrapbook.com. Additionally, academic social networking sites are used by researchers to share their research works. White (2018) noted that academic researchers who want to share their research and review results achieved by colleagues may find academic specific social networking to be quite valuable. Examples are Academic.edu and Research Gate. There are also some social networking sites that are designed to provide entertainment for interested members. Examples include YY.Com, Foursquare, Vine, and Tout. The importance of social networking sites cannot be overemphasized. Nations (2018) asserted that social networking is a nice form of entertainment. It is great for meeting people with similar interests, and is definitely useful for staying in touch with old friends and acquaintances. In the opinion of Hope (2017), social networks help people keep connected with friends and family and are an easy way to find what everyone is up to each day in the social circle. On the part of Yadav (2018), social networking is a powerful tool for teachers that can be used either for personal or professional purposes. More so, UK Essays (2017) posited that social networks can be used to improve the education of adults and students since they already have certain influence on the learners. In addition, Salvation and Adzharuddin (2014) stressed that social networking sites have attracted considerable attention among scholars and educators due to the growing popularity among students and the potential effect on academic performance. Furthermore, Asiedu (2017) believed that the emergence of social networking sites has received a lot of attention and patronage by all ages across the world but significantly people around college or university going age are mostly found on these social networks. Interestingly, Gupta (2015) maintained that leading Universities like University of Southern California, Ryerson University in Toronto and the Ohio State University have successfully integrated social media for the betterment of their students and teachers. In the observation of AlZedjali, Al-Harrasi and Al-Badi (2014), most students believe that social networking sites (SNSs) are useful in education, that their use enhances learning and that they serve as complementary tools in education. More so, Campus Quad in Asiedu (2017) noted that the emergence of instant messaging sites like WhatsApp, Snapchat, Twitter, Instagram and the rest of them have all contributed and still play a role either positively or negatively on students' academic and social lives. In support, Sharma and 
Vishvakarmain Ekechukwu (2017) asserted that the SNSs are sometimes used for educational purposes and sometimes for non-academic purposes, which adversely impact on students' academic performance. The influence of social networking sites on users lies largely on the motive of using such sites, and on how they are being used. Ameyaw, Asante and Asante (2017) gave some reasons for using SNSs to include; update their knowledge on current issues, analyzing and exchange of increasing information, sustaining social contacts and relationships and facilitating delivery of academic activities. Similarly, Al-Zedjali et al (2014) opined that factor of social influence, perceived enjoyment, institute regulation, perceived usefulness, ranking up-life, attractiveness, communicating free of charge, sharing material and course notes, all have strong positive correlations with the intention to use SNSs in education. Furthermore, Prasad and Sumana (2015) noted that majority of students used social networking for leisure purposes and only few use them for educational development purposes. Equally, Prasad and Sumana (2015) posited that some students have become intelligent and smart through positive impact of SNSs, while some have become academically poor due to negative impact of SNSs. In addition, Johnson in Mahmudora (2018) believed that networking sites such as Facebook, Twitter, Instagram and many others take a lot of time from students, thus limiting the time they could have spent studying and thereby influencing students' academic performance negatively.

There are studies to show that excessive usage of SNS can result in negative influence on students' performance. For instance, Khurana (2015) found that students do not think about when and where to use these SNSs and would be seen using them in areas such as lecture halls (while lectures are going on) and also during study and reading hours of their work schedules. Flad (2010) also found that students missed classes, and missed access to counseling services because of events that occurred the night before while on Facebook or on other social networking site. Oginni, Saibu, Awobodu and Alaka (2016) pointed out that social networks today have not greatly contributed to the learning outcome of students because students seem not to understand how purposefully they can take advantage of these network sites for their academic excellence; hence their poor performance in learning outcome. Furthermore, Kirscher and Karpinski in Mingle, Adams and Adjei (2016) observed a negative relationship between Facebook use and academic performance. In their own contribution, Purvis, Rodger and Beckingham (2016) made it clearer that social media is often seen as a distraction; a platform which has so much content linked to so many different connections that it quickly distracts users from their original purpose of visiting the sites. Waqas, Afzal, Zaman and Sabir (2016) suggested that SNSs may badly affect the academic life and learning experiences of the students as social network sites grab the attention of the students and divert it towards non-educational activities. On the contrary, Junco, Heiberger and Loken in Purvis et al (2016) postulated that the use of Twitter in teaching and learning activities has been shown to increase broad engagement in all types of learning activities online and face-toface resulting in higher students' achievement. Supporting that position, Hopkins (2017) maintained that social media can be a powerful enhancement to the way students learn. 
Dragan in Jehopio, Wesonga and Candia (2017) asserted that SNSs facilitates students' engagement in Knowledge sharing, discussion, easy access to information and increased motivation to study. Shehri in Oginni et al (2016) believes that social networking sites have the potential to make learning more student-centered. However, Onyeka, Sajoh and Dalhatu in Asiedu (2017) are of the view that frequent use of social media has no effect on students' academic performance. Besides, Jehopio, et al. (2017) believed that once a student can manage his or her schedules well, he or she is likely to improve significantly in academic performance. By implication, social networking site on its own will not negatively influence students' performance.

Studies have equally revealed the disparity between male and female students on the motive, usage and time spent on social networking sites. For instance, Brenner in Salvation and Adzharuddin (2014) found that 71\% of women were users of SNSs compared with $29 \%$ of men. Similarly, Tsholetso, Maunganidze and Faimau (2017) found out that on average, female students spent more time on the networking sites than their male counterparts. In contrast, Khurana (2015) observed that males' users are more in number compared to female users; and that male users generally derived knowledge based information from these sites. These findings presented here are all subject to further empirical investigation in order to ascertain the influence of the use of social networking sites on the academic performance of students in Entrepreneurship Education.

\section{Statement of the Problem}

The availability of internet accessing devices such as the home computers, laptops, palmtops, notebook, and mobile smart phones have increased the number of users especially university students on social networking sites. The motive and manner in which some students use the internet to visit social networking sites are very worrisome. It is of great concern that too much time spent on social networking sites for nonacademic purposes can negatively influence performance. It is equally of great concern that there are many distractions on the social networking sites that can drain the energy and time students are supposed to use for studies or for doing other academic related activities. It was for these reasons that the study was carried out to empirically determine the influence of the usage of social networking sites on academic performance using students of Entrepreneurship Education.

\subsection{Purpose of the Study}

The main purpose of the study was to ascertain the influence of the usage of social networking sites on academic performance of students in Entrepreneurship Education. Specifically, the study sought to ascertain:

1) The motives for using social networking sites by students.

2) The influence of usage of social networking sites on academic performance of students in Entrepreneurship Education. 


\subsection{Research Questions}

The following research questions guided the study:

1) What are the motives of using social networking sites by entrepreneurship education students?

2) Does the usage of social networking sites influence the academic performance of Entrepreneurship Education students?

\subsection{Hypotheses}

The following hypotheses were tested at 0.05 level of significance:

1. There is no significant difference in the mean responses of male and female Entrepreneurship Education students on the motive of using social networking sites.

2. There is no significant difference in the mean responses of male and female students on the influence of the usage of social networking sites on academic performance of Entrepreneurship Education.

\section{Methodology}

The study adopted a descriptive survey design. A population of 120 students (60 males and 60 females) offering Entrepreneurship Education at the University of Calabar were randomly selected and used for the study. A structured questionnaire with 4-point rating scale consisting of 20 items grouped into two clusters was used for data collection. The instrument was validated by three validates and was further subjected to internal consistency testing using Cronbach alpha which yielded a reliability coefficient of 0.89 . The instrument was administered to the respondents and one hundred percent retrieval was recorded. Mean and standard deviation were used to analyze the data to find answers to the research questions; while t-test statistic was used to test the research hypotheses.

\section{Results}

Research Question 1: What are the motives of using social networking sites by Entrepreneurship Education students?

The data collected to answer the research question one was presented on Table 1.

Table 1: Mean responses on the motives of using social networking sites

\begin{tabular}{|c|l|c|c|c|}
\hline S/N & Item & Mean & Std & Decision \\
\hline 1 & Connecting with family and friends & 2.51 & 1.03 & Agreed \\
\hline 2 & Online business transactions & 2.40 & 0.88 & Disagree \\
\hline 3 & Searching for new friends & 2.55 & 0.93 & Agree \\
\hline 4 & For sports updates & 2.41 & 0.82 & Disagree \\
\hline 5 & Online news & 2.58 & 0.90 & Agree \\
\hline 6 & Entertainments & 2.69 & 0.75 & Agree \\
\hline
\end{tabular}




\begin{tabular}{|c|l|c|c|c|}
\hline \hline 7 & Information shaving & 2.58 & 0.79 & Agree \\
\hline 8 & Chatting & 2.98 & 0.79 & Agree \\
\hline 9 & Downloading music and movies & 3.09 & 0.67 & Agree \\
\hline 10 & Searching for study materials & 3.03 & 0.73 & Agree \\
\hline & Grand mean & $\mathbf{2 . 6 8}$ & & \\
\hline
\end{tabular}

In Table 1, the respondents agreed that their motive of using social networking sites include: connecting with family and friends; searching for new friends; online news; entertainments, information sharing, chatting, downloading music and movies and searching for study materials. However, the respondents indicated that online business transactions and sports updates were not their motives of using social networking sites. The study revealed that the entrepreneurship education students use social networking sites for educational and non-educational purposes as shown above.

Research Question 2: Does the usage of social networking sites influence the academic performance of students of Entrepreneurship Education?

The data collected to answer the research question two is presented in Table 2.

Table 2: Mean responses on the influence of the usage

Of social networking sites on academic performance of students $(\mathrm{N}=120)$

\begin{tabular}{|c|l|c|c|c|}
\hline S/n & Item & Mean & Std & Decision \\
\hline 1 & Create forum to discuss topics on entrepreneurship & 2.91 & 0.95 & Agree \\
\hline 2 & Browse materials to do entrepreneurship education assignment & 2.93 & 0.77 & Agree \\
\hline 3 & Sharing leaning experiences with classmates & 2.86 & 0.94 & Agree \\
\hline 4 & Sharing learning materials & 3.00 & 0.67 & Agree \\
\hline 5 & Assessing reading materials & 3.09 & 0.61 & Agree \\
\hline 6 & Connect students with lecturers & 3.04 & 0.67 & Agree \\
\hline 7 & Collaborative learning with other students & 3.03 & 0.72 & Agree \\
\hline 8 & Knowledge sharing among students from other institutions & 3.13 & 0.74 & Agree \\
\hline 9 & Enable students to be mentored by experienced entrepreneurs & 3.02 & 0.69 & Agree \\
\hline 10 & Allow students to get help from online entrepreneurs & 3.18 & 0.65 & Agree \\
\hline & Grand mean & 3.02 & & Agree \\
\hline
\end{tabular}

In Table 2, the responses of the Entrepreneurship Education students show that social networking sites usage has influence on academic performance of the students. The grand mean of the responses of 3.02 confirmed this.

Hypothesis 1: There is no significant difference in the mean responses of male and female entrepreneurship education students on the motive of using social networking.

The data collected to test the hypothesis is presented on Table 3. 
Table 3: Motive of using social networking sites

by male and female entrepreneurship education students

\begin{tabular}{|c|c|c|c|c|c|c|c|}
\hline$S / N$ & Gender & $X$ & Std & t-cal & t-crit & $\mathrm{df}$ & Decision \\
\hline \multirow[t]{2}{*}{1} & Male & 2.23 & 0.93 & \multirow{2}{*}{3.02} & \multirow{2}{*}{1.96} & \multirow{2}{*}{118} & \multirow{2}{*}{ Reject } \\
\hline & Female & 2.78 & 1.06 & & & & \\
\hline \multirow[t]{2}{*}{2} & Male & 2.15 & 0.79 & \multirow{2}{*}{2.99} & \multirow{2}{*}{1.96} & \multirow{2}{*}{118} & \multirow{2}{*}{ Reject } \\
\hline & Female & 2.61 & 0.93 & & & & \\
\hline \multirow[t]{2}{*}{3} & Male & 2.28 & 0.82 & \multirow{2}{*}{3.25} & \multirow{2}{*}{1.96} & \multirow{2}{*}{118} & \multirow{2}{*}{ Reject } \\
\hline & Female & 2.81 & 0.96 & & & & \\
\hline \multirow[t]{2}{*}{4} & Male & 2.28 & 0.88 & \multirow{2}{*}{1.67} & \multirow{2}{*}{1.96} & \multirow{2}{*}{118} & \multirow{2}{*}{ Accept } \\
\hline & Female & 2.53 & 0.74 & & & & \\
\hline \multirow[t]{2}{*}{5} & Male & 2.20 & 0.68 & \multirow{2}{*}{4.97} & \multirow{2}{*}{1.96} & \multirow{2}{*}{118} & \multirow{2}{*}{ Reject } \\
\hline & Female & 2.95 & 0,94 & & & & \\
\hline \multirow[t]{2}{*}{6} & Male & 2.58 & 0.67 & \multirow{2}{*}{1.58} & \multirow{2}{*}{1.96} & \multirow{2}{*}{118} & \multirow{2}{*}{ Accept } \\
\hline & Female & 2.80 & 0.81 & & & & \\
\hline \multirow[t]{2}{*}{7} & Male & 2.46 & 0.65 & \multirow{2}{*}{1.61} & \multirow{2}{*}{1.96} & \multirow{2}{*}{118} & Accent \\
\hline & Female & 2.70 & 0.90 & & & & Accept \\
\hline 8 & Male & 2.58 & 0.76 & 6.31 & 1.96 & 118 & Reject \\
\hline & Female & 3.38 & 0.61 & & & & \\
\hline 9 & Male & 2.88 & 0.69 & 3,54 & 196 & 118 & Reiect \\
\hline & Female & 3.30 & 0.59 & 0.04 & 1.90 & 110 & Кејес \\
\hline 10 & Male & 2.91 & 0.72 & 164 & 196 & 118 & Accent \\
\hline & Female & 3.13 & 0.70 & & & & \\
\hline & & & & 3.05 & 1.96 & 118 & Reject \\
\hline
\end{tabular}

The item-by-item t-test analysis presented in Table 3 show that six of the items were rejected while four were accepted. Those items rejected have $t$-calculated values greater than the $t$-critical value (1.96). Whereas, those items accepted have $t$-calculated values less than the t-critical value (1.96). This further indicate that there is a significant difference in the mean responses of male and female entrepreneurship education students on the motive of using social networking sites for: connecting with family and friends; online business transactions; searching for new friends; online news; chatting; and search for study materials. On the other hand, there is no significant difference in the mean responses of male and female entrepreneurship education students on the use of social networking sites for: sports updates; entertainments; information sharing and downloading music and movies. However, since the $t$-cal of 3.05 is greater than $t$-crital of 1.96 , the null hypothesis is rejected. This means that there is a significant difference in the mean responses of male and female entrepreneurship education students on the motive of using social networking sites. Therefore, gender has a significant influence on the mean responses.

Hypothesis 2: There is no significant difference in the mean responses of male and female students on the influence of the usage of social networking sites on the academic performance of students of entrepreneurship education.

The result of data analysis of hypothesis 2 is presented in Table 4. 
Table 4: T-test result of the influence of social networking sites usage on academic performance of male and female students in entrepreneurship education

\begin{tabular}{|c|c|c|c|c|c|c|c|}
\hline $\mathrm{S} / \mathrm{N}$ & Gender & $X$ & Std & t-cal & t-crit & df & Decision \\
\hline \multirow[t]{2}{*}{1} & Male & 2.41 & 1.04 & \multirow{2}{*}{6.58} & \multirow{2}{*}{1.96} & \multirow{2}{*}{118} & \multirow{2}{*}{ Reject } \\
\hline & Female & 2.40 & 0.49 & & & & \\
\hline \multirow[t]{2}{*}{2} & Male & 2.76 & 0.88 & \multirow{2}{*}{2.40} & \multirow{2}{*}{1.96} & \multirow{2}{*}{118} & \multirow{2}{*}{ Reject } \\
\hline & Female & 2.10 & 0.60 & & & & \\
\hline \multirow[t]{2}{*}{3} & Male & 2.41 & 0.01 & \multirow{2}{*}{5.83} & \multirow{2}{*}{1.96} & \multirow{2}{*}{118} & \multirow{2}{*}{ Reject } \\
\hline & Female & 3.30 & 0.59 & & & & \\
\hline \multirow[t]{2}{*}{4} & Male & 2.7 & 0.73 & \multirow{2}{*}{3.70} & \multirow{2}{*}{1.96} & \multirow{2}{*}{118} & \multirow{2}{*}{ Reject } \\
\hline & Female & 3.21 & 0.52 & & & & \\
\hline \multirow[t]{2}{*}{5} & Male & 2.88 & 0.52 & \multirow{2}{*}{3.98} & \multirow{2}{*}{1.96} & \multirow{2}{*}{118} & \multirow{2}{*}{ Reject } \\
\hline & Female & 3.30 & 0,61 & & & & \\
\hline \multirow[t]{2}{*}{6} & Male & 2.76 & 0.64 & \multirow{2}{*}{4.94} & \multirow{2}{*}{1.96} & \multirow{2}{*}{118} & \multirow{2}{*}{ Reject } \\
\hline & Female & 3.31 & 0.56 & & & & \\
\hline \multirow[t]{2}{*}{7} & Male & 2.85 & 0.77 & \multirow{2}{*}{2.86} & \multirow{2}{*}{1.96} & \multirow{2}{*}{118} & Raioct \\
\hline & Female & 3.21 & 0.61 & & & & кејест \\
\hline 8 & Male & 2.96 & 0.73 & 250 & 106 & 118 & Poion \\
\hline & Female & 3.30 & 0.72 & 2.50 & 1.90 & 118 & Reject \\
\hline 9 & Male & 2.93 & 0.66 & 145 & 106 & 110 & A conont \\
\hline & Female & 3.11 & 0.71 & 1.45 & 1.96 & 118 & Accept \\
\hline 10 & Male & 2.98 & 0.65 & 3.54 & 196 & 118 & Reject \\
\hline & Female & 3.38 & 0.58 & 3.54 & 1.96 & 118 & Reject \\
\hline & & & & 3.78 & 1.96 & 118 & Reject \\
\hline
\end{tabular}

Table 4 revealed that there is a significant difference in the mean responses of male and female respondents on the influence of the usage of social networking sites on the academic performance of entrepreneurship education students since the $t$-cal of 3.78 is greater than the $\mathrm{t}$-crit of 1.96 .

\section{Summary of the Findings}

The findings of the study revealed that:

1) Entrepreneurship education students used social networking sites for different purposes. In addition, gender has a significant influence on the mean responses on the use of social networking sites by entrepreneurship education students.

2) The usage of social networking sites influences the academic performance of students. It was also found that there is a significant difference in the mean responses based on gender.

\section{Discussion}

Table 1 revealed that entrepreneurship education students use social networking sites for various purpose which include connecting with family and friends; searching for new friends; online news; entertainments; information sharing, chatting; downloading music 
and movies and searching for study materials. The students reported not using social networking sites for online business transactions and sports updates. Also, Table 3 showed that the grand $t$-cal of 3.05 was greater the $t$ - crit of 1.96. This indicates that there is a significant difference in the mean responses of male and female entrepreneurship education students on the motive of using social networking sites.

The findings are in line with A1- Zwdjali et al (2014) that the main motivations behind the usage of social networking sites involve meeting needs for the following: information search; need for entertainments; maintaining relationships; need to meet new people; need to discuss (chatting); need to share media and the need to connect. Mejias, Ajjan and Hart-shornein Aneyaw et al (2017) share the same view that some of the motives for using social networking sites include sharing photos, personal information, videos, profiles and other related content. Furthermore, this finding is in line with Bonds-Raacke and Raacke in Ameyaw et al (2017) that although females and males are both likely to have social network site accounts, the purpose for creating the accounts may vary based on gender. Giles and Price in Flad (2010) equally noted that girls use the internet mainly for things like chatting and downloading music while the boys used it to search for new friends and information.

Table 2 showed that the respondents all agreed that social networking sites usage has influence on academic performance of entrepreneurship education students. Similarly, the test of hypothesis 2 revealed that there is a significant difference in the mean responses of male and female respondents on the influence of the usage of social networking sites on the academic performance of students in entrepreneurship education. This means that gender is a factor that is responsible for the significant difference in the mean responses of the respondents.

The findings do not necessarily agree with Flad (2010) who found that females have more SNSs accounts and spend more time to maintain those accounts; and that these often get in the way of their school work. The finding of this study did not show which of the gender was responsible for the significant difference since the number of male respondents equal the number of the female respondents. The study of Alnjadat, Hmaidi, Samha, Kilani and Hasswan (2019) also supported that female students' access to social media negatively impact their academic performance. This also did not agree with the findings of this study. The researchers here suggest that further investigation may be carried out to determine the gender responsible for the significant difference. However, spending more time on social networking sites, according to Mahmudova (2018), is a sufficient cause for failing examination. We agree with this idea.

\subsection{Implication of the Study}

The implication of the findings of this study is that social networking sites could be used as educational resource in order to improve teaching and learning and subsequently the academic performance of both male and female students. However, usage of the networking sites may also influence academic performance negatively or positively. 
Teachers and counselors need to particularly take notice of these for necessary remedial actions.

\section{Conclusion}

Unarguably, social networking sites could positively or negatively influence students' academic performance depending on how these sites are used.

\subsection{Recommendations}

It is therefore recommended that universities and tertiary institutions should integrate the use of social networking sites into their instructional programmes and use them as platforms for teaching and learning. Lecturers should brace up to the challenge by engaging the students meaningfully in academic activities using these sites. By so doing, the fear of negative influence of social networking sites on students' academic performance will be reduced.

\section{Conflict of Interest Statement}

This paper is an original work of the authors and has not been published or accepted for publication by any other journal.

\section{About the Authors}

Stephen A. Igboke is a Senior Lecturer in Business Teacher Education. He holds B.Sc; M.Ed and PhD in Business Education and MBA in Business Administration (Accountancy). Research Interest is in Business Education, particularly in the area of community participation in the management of Business education programmes.

Patricia A. Olom is a Lecturer in Business Education. She holds a Bachelor's Degree and M.Ed in Business Education. Her research interest is in Entrepreneurship Education.

\section{References}

Alnjadat, R., Hmaidi, M. M., Samha, T. E, Kilani, M. M. \& Hassawan, A. M. (2019). Gender variations in social media usage and academic performance among the students of University of Sharjah. Journal of Taibah University medical sciences, 14 (4), 390-394

Al-Zedjah, K. H., Al-Harrasi, A. S., \& Al-Badi, A. H. (2014). Motivations for using social networking sites by college students for educational purposes. International Journal of Educational and Pedagogical Sciences. 8(8), 1- 4.

Ameyaw, S., Asante, A.E., \& Asante, E. (2017).Gender difference in Social networking sites usage among students: Evidence from Koforidua Technical University, Ghana. Journal of Social Science and Humanities Research. 2(10), 1- 21. 
Asiedu, N. K. (2017). Influence of social networking sites on students' academic and social lives: The Ghanaian perspective. Retrieved from http://digitalcommons.un.edu Llibphilprac/1535.

Boyd. D. M., \& Ellison, N. B. (2008). Social network sites: Definition, history and scholarship. Journal of Computer-Mediated Communication, 13(2008), 210-230.

Cambridge University Reporter (2003). Indicators of academic performance. Retrieved from http://www.admin.cam.ac.uk/reporter/2002-03/weekly/5915.

Ediagbonya, K. (2013). The role of entrepreneurship education in ensuring economic empowerment and development. Journal of Business Administration and Education, $4(1), 35-46$.

Editorial Team (2016). The history of social networking: How it all began. Retrieved from https://1stwebdesigner.com/history-of-social-networking/\#history-ofnetworking.

Ekechukwu, P. C. (2017). The effect of social networking sites on academic performance of students of Abia State Polytechnic, Aba. American Journal of Art and Design, 2(4), 100-104. Doi:10.11648/j.ajad.20170204.13.

Flad, K. (2010). The influence of social networking participation on students' academic performance across gender lines. Retrieved from http://digitalcommons.brockport. edu/edc thesis/3/.

Gupta, P. (2015). Importance of social media in higher education. Retrieved from http://edtechreview.in/trends-insights/insights/2041-social-media-in-highereducation.

Haist, S. A., Wilson, J. F., Elam, C. L., Blue, A. V., \& Fosson, S. E. (2000). The effect of gender and age on medical school performance: An important interaction. Advances in Health Sciences Education, 5(3), 197 - 205.

Hope, C. (2017). Social network. Retrieved from https://www.computerhope.com/jargon/s/societw.htm.

Hopkins, B. (2017). Advantages of using social media for students in education. Retrieved from https://www.academiaapps.com/advantages-social-media-education/

Jamie (2018, June 1). 60 + social networking sites you need to know about in 2018. (Web log post). Retrieved from https://makeawebsite.hub.com/social-media-sites/

Jehopio, P. J., Wesonga, R., \& Candia, D. A. (2017). Effect of online social networking sites usage on academic performance of University Students in Uganda. International Journal of Computer Application, 157(5), 27 - 35.

Khurana, N. (2015). The impact of social networking sites on the youth. Journal of Communication $\mathcal{E}$ Journalism. 5(12), 1- 4.

Lackeus, M. (2015). Entrepreneurship education. Retrieved from http://www.oecd.org/cfe/lead/BGP-Entrepreneurship-in-Education.pdf.

Mahmudova, N. (2018, October 18). How social networking sites affect ADA students' academic performance? Azenews. Retrieved from https://www.azernews .as/analysis/75243.html 
Mingle, J., Adams, M., \& Adjei, E. A. (2016). A Comparative analysis of social media usage and academic performance in public and private senior high schools. Journal of Education and Practice, 7(7), 13-22.

Nations, D. (2018). Social networking. Retrieved from https://www.lifewire.com/what-issocial-networking-3486513.

Oginni, A. M., Saibu, S. O., Awobodu, V. Y., \&Alak, M. O. (2016). Influence of Students' engagement with social networks on their study habits and cognitive skills in science Classroom. International Journal of Digital Society (IJDS), 7(3), 1201-1205

Olokundun, M. A., Ibidunni, A. S., Peter. F., Amaihian, A. B., \& Ogbari, M. (2017). Entrepreneurship educator's competence on University students' commitment to learning and business plan writing. Academy of Strategic Management Journal. 16(2), $1-10$.

Opinkirjo R. (2012). Entrepreneurial approach as the guiding principle of entrepreneurship education. Retrieved from https://www.opinkirjo.fi/en/activity/entrepreneurshipeducation/objectives

Prasad, K. K., \& Sumana, S. (2015). Effect of social networking sites on student's academic performance in SIMS, Mangalore: An investigative study. International Journal of Management Research. 3(3), 39 - 48.

Purvis, A., Rodger, H., \& Beckingham, S. (2016). Engagement or distraction: The use of social media for learning in higher education.

Romer, D. (1993). Do students go to Class? Should they? Journal of Economic Perspectives, 7(3), 167-174.

Salvation, M., \& Adzharuddin, N. A. (2014). The influence of social network sites upon academic performance of Malaysian Students. International Journal of Humanities and Social Science, 4(10), 131-137.

Tsholetso, T., Maunganide, L. \& Faimau, G. (2017). Online social networking and academic performance at the University of Botswana. Mosenodi Journal, 20(2), 4-15.

Vakili, F., Tahmasebi, N., Tahmasebi, S., \&Tahmasebi, D. (2016). Role of education in entrepreneurship development. Journal of Ecophysiol. Occup. Hlth, 16(3\&4), 78-87.

Walker, M. (2011). The history of social networking. Retrieved from https://www.webmasterview.com/2011/08/social-networking-history/

Waqas, A., Afzal, M., Zaman, F., \& Sabir, M. (2016). The Impact of social networking sites' usage on the academic performance of University Students of Lahore, Pakistan. International Journal of Science and Management, 3(4), 1-10.

White, M. G. (2021). What types of social networks exists? Retrieved from https://social networking.lovetoknow.com/what-types-of-social-networks-exists.

Wikipedia (2019). Academic achievement. Retrieved from https://en.wikpiedia.org/wiki/ Academic achievement.

Yadav, R. (2018). What is the use and importance of social networking in teaching economics? Retrieved from https://www.quora.com/what-is-the-use-and-importance-ofsocial-networking-in-teaching-economics. 

will be applied to their work. Under the terms of this license, no permission is required from the author(s) or publisher for members of the community to copy, distribute, transmit or adapt the article content, providing a proper, prominent and unambiguous attribution to the authors in a manner that makes clear that the materials are being reused under permission of a Creative Commons License. Views, opinions and conclusions expressed in this research article are views, opinions and conclusions of the author(s). Open Access Publishing Group and European Journal of Education Studies shall not be responsible or answerable for any loss, damage or liability caused in relation to/arising out of conflicts of interest, copyright violations and inappropriate or inaccurate use of any kind content related or integrated into the research work. All the published works are meeting the Open Access Publishing requirements and can be freely accessed, shared, modified, distributed and used in educational, commercial and non-commercial purposes under a Creative Commons Attribution 4.0 International License (CC BY 4.0). 